\title{
The Effect of Design
}

\author{
A phenomenological contribution to the quiddity of design presented in geometrical order \\ Stéphane Vial, \\ University of Nîmes, Researcher at the ACTE Institute, Pantheon-Sorbonne University
}

\begin{abstract}
This paper suggests defining three criteria to differentiate design and non-design, using the concept of effect in a phenomenological perspective. The central concept of this article is the concept of "effect of design," defined as a three-dimensional result that occurs through usage and turns it into an "experience-to-live." The three dimensions of the effect of design are the "ontophanic effect," the "callimorphic effect" and the "socioplastic effect." This approach is presented in the form of a philosophical manifesto in the geometrical style inspired by Euclid's Elements or Spinoza's Ethics.
\end{abstract}

This article includes 1 general overview of the issue, 5 definitions, 3 axioms, 3 hypotheses and 3 developments.

Keywords: design philosophy, quiddity of design, effect of design, ontophanic effect, callimorphic effect, socioplastic effect

\section{PROBLEM}

Everything that surrounds us has been drawn by someone. The places we love, work and die in have been drawn by someone. The objects that we cherish, keep or abandon, were designed by someone. All aspects of life are concerned by design, from living room furniture to offices, from urban spaces to hospital rooms, from public transport to classrooms, from kitchen utensils to heating devices. However, it is not because an artefact has been drawn that it has been designed. Artisans draw, engineers draw and technicians draw too. But they do not design. This is why it is an exaggeration to say that "everything is now a matter of design" (Flusser 1999) or that we live in a "world of total design" (Foster 2003). Even if everything is potentially concerned by design, not everything is design. And for good reason: if design cannot do without industry, industry can easily do without design. Many goods and services are manufactured without any design process having taken place. Design is not necessarily integrated into industrial production. In France, for example, it is even less the case than elsewhere, if one believes the most famous French designer: "The French industries are not interested in design, it is not in their culture, this is the difference with Italy, which integrates it as a natural element," explains Philippe Starck'. While design appeared from the moment it acknowledged industry, industry does not necessarily acknowledge design. Which proves that design should not be confused with industrial production. It is rather a kind of supplement to industry, which only occurs under certain specific conditions. The question is to know what these conditions are. What gives a space, a product or a service the quality of design? How to distinguish a design artifact from an ordinary industrial object, a craft object or a work of art? In a word, what is the essence or the quiddity of design?

That is a question that only the philosophy of design can answer. In the same way as the philosophy of art questions, in an ontological manner, the conditions under which an object becomes a work of art, the philosophy of design must question, in a phenomenological manner, the conditions under which an artifact becomes a designed artifact. It is necessary to distinguish "when one refers to design as a practice ('this is design') from when one addresses it 'in reference to an object ('this is a design'), and from when one refers to it as a 'criterion of taste ('this is good design')" (Remaury 2006). What we are referring to here is indeed design in reference to an artifact, that is to say, design as the constituting essence of a category of beings. Questioning the essence or the quiddity of design therefore means questioning the criteria differentiating design and non-design. In this objective, I suggest calling "effect of design" what design is working towards. 


\section{DEFINITIONS}

I.

By usage, I mean the usage of a designed artifact as an experience-to-live.

II.

By experience-to-live, I mean a manner of acting, feeling and thinking that results from an effect of design.

III.

By designed artifact, I mean what has been the matter of a design process.

IV.

By design process, I mean the creative approach aiming at producing an effect of design.

V.

By effect of design, I mean a three-dimensional result occurring through usage and turning it into an experience-to-live.

\section{AXIOMS}

I.

A designed artifact is not necessarily an object. (According to Definition III.)

II.

The three dimensions of the effect of design are: the ontophanic effect, the callimorphic effect and the socioplastic effect.

(See Development I, Development II and Development III.)

III.

A form can be spatial, voluminous, textile, graphic or interactive.
Design is the creative activity aiming at creating experiences-to-live with the help of forms.

PROOF

Design is a process (See Definition IV). Its aim is to create experiences-to-live by transforming usages through an effect of design (See Definitions I, II and V).

\section{COROLLARY}

The value of experience is the fundamental value of design.

\section{PROPOSITION II}

Design is not the field of objects, but the field of effects.

PROOF

The finality of the design process is not to produce objects, but to produce effects (See Definition IV). A designed artifact, to the extent to which it has been the matter of a design process (See Definition III), may be a physical product or an intangible service, a digital interface or a social device (See Axiom I). It only becomes a designed artifact when it liberates an effect of design that the human subject can experience.

\section{COROLLARY}

The system of design is defined by all the areas of the life of forms that are regarded as the fields of application of the design process: architecture, housing, urban space, furniture, clothing, consumer products, printed materials, digital interfaces, video games, websites, social structures, etc. That is why, depending on the type of forms to which it refers (See Axiom III), design can be described as "environmental design," "product design," "industrial design," "fashion design," "graphic design," “digital design," "social design," etc. However, despite the diversity of its fields of application, design remains 
one and indivisible. "Whether you create emotion by designing a spoon or a space, for me, it's the same," declares French designer Patrick Jouin².

\section{NOTE}

Design is not an area of architecture, it is architecture that is an area of design.

\section{PROPOSITION III}

\author{
Industrial design is only an area of design.
}

PROOF

The industrial production tool is only a tool. It is not in itself necessary to produce an effect of design. It has only been an historic opportunity to invent design, as the industrial mechanization techniques that emerged in the 18th and 19th centuries, because they were particularly aggressive to man, had to be enchanted and humanized more than any other artefact so far. Facing the ravages of industrialization on humanity, we had no other choice but to invent design, that is to say the idea of enchanting technical objects. Industry has been the first field of application of design. However, the need for enchantment is not specific to industry. It potentially affects all areas of life. That is why today design largely goes beyond the industrial world to which it would be absurd and illusory to limit it. An effect of design, that is to say an experience-to-live through form (According to Proposition I), may very well occur with the help of other tools than those of industry, such as public services, the voluntary sector, the city or town, the internet and even crafts.

\section{COROLLARY}

An urban device or a digital service can have more of an effect of design than an industrial mass-produced object.

\section{NOTE}

Design is the art of enchanting everyday life through form.

\section{DEVELOPMENT I}

\section{THE ONTOPHANIC EFFECT}

Before being a space, a product or a service, design is predominantly an effect that occurs within a space, a product or a service. This means that design is not a being but an event, not a thing but an impact, not a property but a repercussion. As stated by Japanese designer Kenya Hara, design does not mean conceiving "things that are" but conceiving "things that happen" (Hara, 2007, p. 467) Indeed, design is somehow performative: before being a thing, it is something that happens. According to Kierkegaard, one could say that it is a "reduplication"3: it occurs while being made or, rather, while becoming. The being of design is that of becoming. Being, for design, means happening. Such is its phenomenality. Contrary to what a too hasty interpretation might suggest, effect must not be understood here as a logical concept in the sense of a "consequence" (correlate of cause); effect must be understood here as a phenomenological concept in the sense of the creative outbreak of the apparition, the inventive dynamic of the manifestation, as it structures the experience (correlate of perception). What appears as an experience-to-live in the field of our existence (See Definitions I and II) as it was intentionally built, falls within the concept of design.

The first dimension of the effect of design is what I first called the effect of experience to highlight the fact that design is experienced, felt and experimented. It is indeed how one recognizes it. Where there is design, users immediately feel its effect, because their experience is thereby instantly transformed and improved. Take the example of the iMac, whose concept, although infinitely simple, is a stroke of genius. The iMac is a desktop computer created by Apple and only comprises of a flat screen, without a tower or external CPU. Everything is in the screen: the motherboard, the hard disk and the CD / DVD player / burner. You just have to plug it in and place it on your desk, and you instantly save room. What was first a simple desktop computer triggers a new way of furnishing your home and even produces effects on how you design your interior decor. The value of experience is therefore at the heart of design. Where there is nothing to live or to experience, there is no effect of design.

Design is nothing other than a generator of experiences-to-live, whether through consumer products, urban installations or digital services. It changes 
the quality of the experience of usage, as you can use a bathroom, a watch or a phone without being offered any quality of experience. In this case, you experience basic usage: water flows into the shower base, hands display seconds on a dial, and a shrill alarm sounds to warn you of an incoming call. But if you can use your bathroom with sensuality, if you can check the time with enchantment or use your phone in a fun way, you experience waves of pleasure in the most trivial acts, which increases the experienced quality of your experience of existing. Hence the inestimable added value design can bring to industrial production and, more generally, to any device involving users. This is the meaning that must be given to the idea of enchanting life through design: increasing the quality of the experience, whatever it is. That is why I now call "ontophanic effect" this first dimension of the effect of design (Vial, 2013). Design does nothing but change the qualitative regime of the experience of existing, that is to say, the experience of being-present-in-theworld, by influencing the way being (ontos) appears to us (phaino). It intentionally offers new ontophanies that are the matter of new experiences-to-live. This is why design is not the field of objects, but the field of effects (See Proposition II).

\section{DEVELOPMENT II}

\section{THE CALLIMORPHIC EFFECT}

If it is essential and fundamental, the ontophanic dimension is not sufficient to determine what actually characterizes an effect of design because it is readily found, under other forms, in works of art and artefacts in general. For an effect of design to take place, there must also be a callimorphic effect. By this, I mean an effect of formal beauty. Designing something means first to create forms (i.e. spatial, voluminous, textile, graphic or interactive, see Axiom III) and try to give them a style, a character, an expression. When there is no elegance or finesse of line, purity of volume or balance of mass, poetry of contours, perfection of drawing, graphic or visual seduction or attraction, in a word when there is no harmony of forms, no callimorphy and no design can take place. Design begins with the enjoyment inherent to the perception of formal beauty. This is not trivial or incidental. The search for beauty is a fundamental psychological need of man. As Freud has shown, the perception of formal beauty provides an "incentive bonus," or added pleasure, which is a substitute for the instinctual satisfaction, which we are forced to give in to in real life. We therefore need it to bear our existence or enchant it. Design therefore plays a vital role in our postmodern societies. It now assumes the responsibility of satisfying our basic needs for beauty as "Beauty is now on the side of industrial engineering and it has left the field of art, henceforth freeing itself from its tutelage" (Séris, 1994). That is why, in France, one has long wanted to define design as "industrial aesthetics," (excessively) considering that the search for beauty in industrially manufactured objects was at the heart of design.

And that is why the history of design is so marked by quarrels of style that are actually quarrels over the manner in which the beauty of forms must be conceived. What is Art Nouveau other than a callimorphic theory founded on the premise of ornament? "Ornament completes form, of which it is the extension, and we recognize the meaning and justification of ornament in its function. This function consists in 'structuring' the form and not in 'adorning' it," as Henry Van de Velde used to say (quoted by Quarante, 1994, p. 56). What is functionalism other than a callimorphic theory according to which beauty comes from the adaptation of a function, taking advantage of the rejection of decor? "'Ornament' was once a word meaning 'beautiful.' Today, thanks to my life's work, it is a word that means 'lower value'," wrote Adolf Loos in 1908. What is modern architecture other than a callimorphic theory based on "five points"? These five points are, as Le Corbusier has formulated them, pure concepts of form: pilots, roof gardens, free design of the ground plan, horizontal window and free design of the façade. What is Streamline other than a callimorphic theory founded on the premise of aerodynamics? And so on... until today. Nowadays, the dominant callimorphic premise focuses on purity and lightness. It can be found in the work of every designer and in all specialties: in product design, with Philippe Starck's Marie chair, totally transparent and made from a single mould; in graphic design, with Kenya Hara's aesthetics of the void, who chooses to place the MUJI brand logo in the middle of the horizon; in the design of spaces and architecture, with the delicate and streamlined structures of Kazuyo Sejima, such as those at the New Museum of Contemporary Art in New York and the Rolex Learning Center at the Ecole Polytechnique fédérale in Lausanne. 


\section{DEVELOPMENT III}

\section{THE SOCIOPLASTIC EFFECT}

The third dimension of the effect of design is its socioplastic dimension. By socioplastic effect, I mean an effect of social reform. By creating new material forms, the aim is to simultaneously change the social forms of life and to invent new ways of existing together, side by side. This is made possible by the fact that the forms that arise from design, unlike those that arise from art, have a use value, that is to say a material utility. They are marketed to meet certain needs and, as such, they circulate in the various areas of everyday life through the whole social fabric. Design begins where there is already a use value. However, the use value itself produces no effect of design. It is simply a prerequisite that creates the possibility of a socioplastic effect, which has been searched for since the origins of the discipline. Remember for example William Morris, who placed in the decorative arts the hope of a social revolution that could save workers from their misery and the artist from mechanical alienation, in order to produce a good quality living environment for all. This desire to transform society and bring about a better world is the utopian heart of design. It assumes that the forms created by designers are not only plastic forms but socioplastic forms, that is to say forms capable of acting on society and remodelling it. Designers have indeed always assigned to the forms they created all kinds of psychological and moral powers that may affect the human environment. According to Loos, for example, “Ornament is not merely produced by criminals, it commits a crime itself by damaging national economy and therefore its cultural development" (Loos, 1997); its disappearance should allow for the acceleration of the cultural development of the people and bring them into adulthood!

If design is first and foremost a matter of theory of form, this theory of form is always a theory of both man and society. Design is always a "sociodesign," creator of civilization, which seeks to contribute to "social sculpture" (Stiegler, 2006). This is where its moral foundation lies. Not mistaking the means for the end is the only way for design to put its efforts into the service of man. If the market is its favourite means, then its most essential end is to contribute to social sculpture, beyond capital. Trying to improve our quality of life, to create other ways of living, to imagine new ways of being together and to address the major issues of the future: such are some of the real challenges of design, as summarized by Alain
Findeli: "the end or purpose of design is to improve or at least maintain the 'habitability' of the world in all its dimensions" (Findeli, 2010).

That is why a project like Vélib', Paris' self-service bike rental, offers a good example of the effect of design: beyond the obvious callimorphic effect that results from the streamlined forms of the bicycles and of their parking terminals (which were designed by Patrick Jouin), Vélib' produces a considerable socioplastic effect: it changes our way of living in the city, of looking at it, moving in it, behaving in it. If you add the fact that Vélib' works with a dedicated mobile application, which informs the user in real time of the location of the different terminals and the availability of bicycles, you then obtain a service that transforms in an exceptional way our urban experience and mobility, that is to say the liveability of the city.

\section{APPENDIX}

\section{RELATIONS TO OTHER DESIGN DEFINITIONS}

By focusing on the "designerly ways of knowing", classical definitions of design by Archer (1979) and Cross $(1982,2001)$ restricted the scope of the design act to the "conception part" of it, which deals with the specific logics and processes that designers adopt when doing design. Findeli well showed that "the 'conception' part is only one of the two main moments or constituents of a design project, the 'reception' part being the other one"; indeed, "the design act is incomplete if we do not address what happens to the project's output once it starts its life in the social world" (Findeli, 2010, p. 289). As an original phenomenological approach, the theory of "The Effect of Design" (TED) presented in this paper is an attempt to define what design is from a 'reception' point of view, which is usually not considered by design researchers. Design, within its reception regime, is a 'phenomenon-in-the-world' which is given to our perception and experience in the form of an Effect in our lives.

\section{NOTES}

1. Interview with Philippe Starck. In B. Flamand (Ed.). (2006). Le design: essais sur des théories et des pratiques (1st ed.). Paris: Institut français de la mode \& Éditions du Regard. 
2. Patrick Jouin, video interview available on the Rue89 website at: http://www.rue89.com/artnet/2010/05/01/patrick-jouin-grand-chef-nantais-du-design-parisien-149784 (last visited on 24th February 2014)

3. "Rédupliquer, c'est être ce qu'on dit". Søren Kierkegaard, Journal, II, p. 292 (Pap. IX A 208), Paris, Gallimard, 1941-1961.

\section{REFERENCES}

Archer, B. (1979), The three Rs. Design Studies, 1(1).

Cross, N. (1982), Designerly ways of knowing. Design Studies, 3(4).

Cross, N. (2001), Designerly ways of knowing: design discipline versus design science. Design Issues, 17(3).

Findeli, A. (2010). Searching for design research questions: some conceptual clarifications. Questions, hypotheses \& conjectures: discussions on projects by early stage and senior design researchers. Bloomington, IN: iUniverse.

Flusser, V. (1999). The shape of things: A philosophy of design. London: Reaktion Books.

Foster, H. (2003). Design and crime (and other diatribes). London: Verso.

Hara, K. (2007). Designing design. Baden: Lars Müller Publishers.

Loos, A. (1997). Ornament and crime: Selected essays. Riverside, CA: Ariadne Press.

Quarante, D. (1994). Éléments de design industriel(2e ed). Paris: Polytechnica. Original publication, Paris: Maloine, 1984.

Remaury, B. (2006), Les usages culturels du mot design. In B. Flamand (Ed.), Le design: essais sur des théories et des pratiques. Paris: Institut français de la mode \& Éditions du Regard.

Séris, J.-P. (1994). La technique. Paris: Presses Universitaires de France.

Stiegler, B. (2006). Du design comme sculpture sociale. In B. Flamand (Ed.), Le design: essais sur des théories et des pratiques. Paris: Institut français de la mode \& Éditions du Regard.

Vial, S. (2013). Le geste de design et son effet: vers une philosophie du design. Figures de l'art, 25, 93-105.

\section{CORRESPONDENCE}

Stéphane Vial, Associate Professor of Design, Université de Nîmes, Rue du Docteur Georges Salan, 30021 Nîmes Cedex 1, France

E-mail: stephane.vial@unimes.fr

Twitter:@svial

Published online 28 July, 2015

ISSN 1749-3463 print/ISSN 1749-3471

http://dx.doi.org/10.14434/artifact.v3i4.5137

(C) 2015 Artifact 